УДК 342.9

DOI https://doi.org/10.32844/2618-1258.2019.5-2.32

РАДЧУК А.А.

\title{
ЗАГАЛЬНІ АСПЕКТИ ДОКАЗУВАННЯ В СПРАВАХ ЗА ЗВЕРНЕННЯМИ СУБ'ЄКТІВ ВЛАДНИХ ПОВНОВАЖЕНЬ
}

\begin{abstract}
У статті проаналізовано загальні аспекти доказування в справах за зверненнями суб'єктів владних повноважень. Що стосується справ про застосування адміністративними судами санкцій за зверненнями суб'єктів владних повноважень, то доказування в цих справах, у силу особливостей, здійснюється простіше й зводиться до встановлення об'єктивної істини в питанні, чи дійсно існують у реальній дійсності підстави для застосування тих чи інших санкцій адміністративним судом. У свою чергу тягар доказування наявності підстав для застосування санкцій покладається виключно на суб' єкта владних повноважень. 3'ясовано, що доказування в справах за зверненнями суб' єктів владних повноважень підпорядковується підставам звернення суб'єктів владних повноважень 3 адміністративними позовами, абсолютно конкретно визначені в законах. Тобто головне завдання суду - перевірка того, наскільки вірно на підставі наявних доказів суб'єкт владних повноважень здійснив юридичне діяння, яке стало підставою звернення до адміністративного суду. Якщо така кваліфікація здійснена вірно, то адміністративний суд може прийняти конкретно визначене рішення, яке також визначено законом, наприклад, накласти штраф, видворити за межі України, позбавити повноважень тощо. Наголошено, що документ, на підставі якого суб'єкт владних повноважень звертається з позовом до адміністративного суду, одночасно є доказом у цій справі. Особливість доказування в справах за зверненнями суб'єктів владних повноважень полягає у тому, що суб'єкт владних повноважень як позивач зобов'язаний доказувати наявність певних обставин, відповідно відповідач (фізична чи юридична особа) доводить відсутність цих обставин чи спростовує їх, тобто, якщо відповідач не надав підтверджених доказів своїх заперечень, суд має задовольнити позов суб'єкта владних повноважень. Зроблено висновок, що ознаки оцінки доказів у справах про застосування санкцій за зверненнями суб'єктів владних повноважень залежать від того, що іiі проведення виражає якісні характеристики доказів, які є умовами процесу доказування та оцінюються за внутрішнім переконанням суду, яким він має керуватися при прийнятті рішення.
\end{abstract}

Ключові слова: адміністративне судочинство, доказ, доказування, суб'єкт владних повноважень, звернення суб'єктів владних повноважень.

The article analyzes the general aspects of proof in cases of appeals by authorities. As for cases concerning the application of sanctions by administrative courts on the petitions of the subjects of power, the proof in these cases, by virtue of the peculiarities, is simpler and reduces to establishing the objective truth in the question whether there are really grounds for applying them or other sanctions by an administrative court. In turn, the burden of proving that there are grounds for imposing sanctions rests solely on the subject of power. It is found that the evidence in cases of appeals of the authorities has the following peculiarities, namely, the grounds for the application of the authorities with administrative claims are absolutely specified in the law. That is, the main task of the court is to check whether, on the basis of the available evidence, the subject of power has carried out the legal qualification of the act, which became the basis for appeal to the administrative court. If this qualification is correctly implemented, the administrative court may make a specific decision, which is also stipulated by law, for example, to impose a fine, expel from Ukraine, deprive of authority, etc. It is emphasized that the document

(C РАДЧУК А.А. - здобувач наукового ступеня кандидата юридичних наук (Науково-дослідний інститут публічного права) 
on the basis of which the authority subject to a lawsuit before the administrative court is at the same time evidence in this case. The peculiarity of proving in cases of petitions of the subjects of power is that the subject of power, as the plaintiff, is obliged to prove the existence of certain circumstances, respectively the defendant (natural or legal person) proves the absence of these circumstances or denies them, so if the defendant has not provided substantiated evidence of its objections, the court must satisfy the claim of the subject of power. It has been concluded that the peculiarities of the evaluation of evidence in cases of application of sanctions by petitioners of power are that its conduct expresses the qualitative characteristics of the evidence, which are the conditions of the process of proof and are assessed by the internal conviction of the court, which should be guided in its decision.

Key words: administrative proceedings, evidence, subject of authority, appeal of subjects of authority.

Вступ. Доказування в адміністративному судочинстві є процесуальною та розумовою діяльністю суб'єктів доказування, яка спрямована на пізнання за допомогою доказів юридичних фактів, що мають значення для правильного вирішення справи. Водночас доказування виступає пізнавальним процесом, якому притаманна єдність діяльності практичної, що суворо регламентована нормами процесуального закону, та розумової, що підпорядковується правилам логіки й грунтується на пізнанні обставин справи. Саме пізнання дозволяє адміністративному суду й учасникам адміністративного провадження одержати інформацію, що впливає на встановлення істини в справі, і постановити на основі встановлених юридичних фактів законне й обгрунтоване рішення [5, с. 79].

Попри те, що доказування в адміністративному судочинстві має відмінності від доказування в інших судових процесах, можна стверджувати, що відмінності в доказуванні також притаманні окремим справам всередині адміністративного судочинства, і це стосується насамперед адміністративного судочинства в справах за зверненнями суб'єктів владних повноважень.

Все це обумовлює актуальність та своєчасність обраної теми дослідження.

Огляд останніх досліджень. Окремим питанням розгляду адміністративними судами прав за зверненнями суб'єктів владних повноважень приділяли увагу у свої роботах А.В. Константий, С.М. Мельник, Є.В. Устименко та інші, але комплексний розгляд цієї проблеми в літературі майже не висвітлювався.

Постановка завдання. Мета статті полягає в тому, щоб на підставі досліджень позицій учених-юристів і нормативно-правової бази адміністративно-процесуального права визначити загальні аспекти доказування в справах за зверненнями суб'єктів владних повноважень.

Результати дослідження. Як стверджують сучасні науковці, інститут доказів (або інакше - доказів і доказування) має чималу специфіку в адміністративному судочинстві. Незважаючи на багато спільних рис з аналогічним інститутом в інших видах судочинства, насамперед у цивільному, інститут доказів в адміністративному процесі є одним із тих, що суттєво відрізняється. Така відмінність зумовлена дією принципу офіційного з'ясування всіх обставин справи, а також презумпцією вини відповідача [2, с. 335].

Відповідно до статті 72 Кодексу адміністративного судочинства України (далі - КАСУ) доказами в адміністративному судочинстві є будь-які дані, на підставі яких суд встановлює наявність або відсутність обставин (фактів), що обгрунтовують вимоги й заперечення учасників справи, та інші обставини, що мають значення для вірного вирішення справи. Ці дані встановлюються судом на підставі показань свідків, письмових, речових і електронних доказів, висновків експертів [3].

3 цієї норми випливає, що головним завданням суду при вирішенні адміністративних справ $\epsilon$ встановлення наявності або відсутності обставин, що обгрунтовують вимоги й заперечення осіб, які беруть участь у справі.

Якщо судом розглядається справа за позовом про визнання неправомірними рішень, дій або бездіяльності суб' єкта владних повноважень, перед ним постає завдання оцінити діяльність саме суб'єкта владних повноважень з точки зору того, чи дійсно оспорювані рішення чи дії порушують права, свободи чи інтереси фізичної або юридичної особи.

У справах за зверненнями суб'єктів владних повноважень ситуація кардинально інша. По-перше, підстави звернення суб'єктів владних повноважень 3 адміністративними позовами 
абсолютно конкретно визначені в законах. Тобто тут головним завданням суду є перевірка того, наскільки вірно на підставі наявних доказів суб'єкт владних повноважень здійснив юридичну кваліфікацію діяння, яке стало підставою звернення до адміністративного суду. Якщо така кваліфікація здійснена вірно, то адміністративний суд може прийняти конкретно визначене рішення, яке також визначено законом, наприклад, накласти штраф, видворити за межі України, позбавити повноважень тощо. По-друге, документ, на підставі якого суб'єкт владних повноважень звертається з позовом до адміністративного суду, одночасно є доказом у цій справі.

У контексті цього дещо незвично виглядають норми, які стосуються обов'язку доказування. Відповідно до частини першої статті 77 КАСУ кожна сторона повинна довести ті обставини, на яких грунтуються іiї вимоги та заперечення, крім випадків, встановлених статтею 78 цього Кодексу. В адміністративних справах за зверненнями суб'єктів владних повноважень, особливо в справах про застосування санкцій, заперечення відповідача може відображати лише позицію, протилежну позиції позивача [3].

Але проблема полягає в тому, що в більшості випадків заперечення позивача можуть грунтуватись на документах того самого суб'єкта владних повноважень, який виступає позивачем. Тобто констатувати наявність або відсутність певних обставин може тільки суб'єкт владних повноважень у силу своєї компетенції. Так, наприклад, наявність чи відсутність порушень правил перебування іноземців в Україні може констатувати лише орган виконавчої влади в справах міграції або Служба безпеки України, наявність чи відсутність порушень у сфері державних лотерей чи грального бізнесу - органи державної фіскальної служби або поліції, наявність чи відсутність порушень у сфері пожежної безпеки - органи Державної служби з надзвичайних ситуацій тощо.

Отже в досліджуваних справах суб'єкт владних повноважень має доказувати наявність певних обставин, а відповідач - фізична чи юридична особа - їх відсутність. Але цілком зрозуміло, що доказувати відсутність певних обставин набагато складніше, ніж їх наявність. Виключення складають справи про застосування заходів впливу за результатами державного контролю, якщо до моменту прийняття рішення в справі виявлені порушення були усунені, це підтверджено відповідними доказами й застосування заходів впливу у вигляді, наприклад, зупинення роботи підприємства, втрачає сенс.

Певні особливості мають місце й у справах про застосування санкцій за зверненнями суб' єктів владних повноважень стосовно оцінки доказів. Відповідно до частини першої статті 90 КАСУ суд оцінює докази, які $є$ в справі, за своїм внутрішнім переконанням, що грунтується на їх безпосередньому, всебічному, повному та об'єктивному дослідженні. Крім того, в частині другій цієї ж статті зазначено, що жодні докази не мають для суду наперед встановленої сили. У цьому контексті інтерес викликають положення статті 78 стосовно підстав для звільнення від доказування. Відповідно до частини четвертої цієї статті обставини, встановлені рішенням суду в господарській, цивільній або адміністративній справі, що набрало законної сили, не доказуються при розгляді іншої справи, в якій беруть участь ті самі особи або особа, стосовно якої встановлено ці обставини, якщо інше не встановлено законом. У свою чергу, відповідно до частини шостої вирок суду в кримінальному провадженні, ухвала про закриття кримінального провадження i звільнення особи від кримінальної відповідальності або постанова суду в справі про адміністративне правопорушення, які набрали законної сили, є обов'язковими для адміністративного суду, що розглядає справу про правові наслідки дій чи бездіяльності особи, стосовно якої ухвалений вирок, ухвала або постанова суду, лише в питанні, чи мали місце ці дії (бездіяльність) та чи вчинені вони цією особою [3; 7].

Взагалі, оцінка доказів $є$ ключовим моментом доказування і найбільш складною діяльністю суддів. Відповідно до статті 90 КАСУ, суд оцінює докази, які є у справі, за своїм внутрішнім переконанням, що грунтується на їх безпосередньому, всебічному, повному та об'єктивному дослідженні. Суд оцінює належність, допустимість, достовірність кожного доказу окремо, а також достатність і взаємний зв'язок доказів в їх сукупності. Суд надає оцінку як зібраним у справі доказам у цілому, так і кожному доказу (групі однотипних доказів), що міститься у справі, мотивує відхилення або врахування кожного доказу (групи доказів) [3].

3 наведеної норми випливає, що оцінка доказів відбувається по таким параметрам, як належність, допустимість, достовірність і достатність.

Відповідно до статті 73 КАСУ належними є докази, які містять інформацію щодо предмета доказування. Предметом доказування є обставини, які підтверджують заявлені вимоги чи заперечення або мають інше значення для розгляду справи й підлягають встановленню при ухваленні судового рішення [3]. 
Сутність допустимості доказів, відповідно до статті 74 КАСУ, полягає в тому, що суд не бере до уваги докази, які одержані з порушенням встановленого законом порядку. Обставини справи, які за законом мають бути підтверджені певними засобами доказування, не можуть підтверджуватися іншими засобами доказування [3].

У свою чергу, відповідно до статті 75 КАСУ достовірними є докази, на підставі яких можна встановити дійсні обставини справи [3].

Достатніми, в силу вимог статті 76 КАСУ, є докази, які у своїй сукупності дають змогу дійти висновку про наявність або відсутність обставин справи, які входять до предмета доказування. Питання про достатність доказів для встановлення обставин, що мають значення для справи, суд вирішує відповідно до свого внутрішнього переконання [3].

Як зазначають сучасні дослідники, складність оцінки доказів, що зумовлює, у свою чергу, одну з основних іiі проблем, полягає в тому, що результат завжди має належну процесуальну форму, проте сам процес оцінки виходить за межі процесуальних дій, оскільки є розумовим процесом, на який також впливають фактори, що не мають правового характеру [8, с. 179].

Дійсно, вказівка, що суд оцінює докази за своїм внутрішнім переконанням, вимагає звернути увагу на те, як це переконання має формуватися і чи дійсно результат такого переконання не може бути формалізований.

Незважаючи на те, що за суддею зберігається право на власне переконання, відповідно до частини четвертої статті 90 КАСУ суд надає оцінку як зібраним у справі доказам у цілому, так і кожному доказу (групі однотипних доказів), що міститься в справі, мотивує відхилення або врахування кожного доказу (групи доказів). До того ж у частині четвертій статті 246 КАСУ зазначено, що у мотивувальній частині рішення зазначаються [3]:

1) обставини, встановлені судом, та зміст спірних правовідносин, з посиланням на докази, на підставі яких встановлені відповідні обставини;

2) докази, відхилені судом, та мотиви їх відхилення;

3) мотивована оцінка кожного аргументу, наведеного учасниками справи, щодо наявності чи відсутності підстав для задоволення позову.

Іншими словами, суд у судовому рішенні повинен аргументувати всі без виключення параметри оцінки доказів, тобто показати, на підставі чого в нього виникло саме таке, а не інше переконання.

На відміну від цього в попередній редакції КАСУ в статті 163 стосовно змісту мотивувальної частини рішення (постанови) було лише дві вимоги [3]:

- зазначення встановлених судом обставин із посиланням на докази, а також мотивів неврахування окремих доказів;

- зазначення мотивів, з яких суд виходив при прийнятті постанови, і положення закону, яким він керувався.

Фактично можна стверджувати, що з прийняттям нової редакції КАСУ внутрішнє переконання суду, яким він має керуватися при прийнятті рішення, набуло процесуального оформлення. На нашу думку, ця обставина має надзвичайно важливе значення для розгляду й вирішення адміністративних справ про застосування санкцій за зверненнями суб'єктів владних повноважень.

Ще одна особливість, на яку варто звернути увагу, стосується повноважень адміністративного суду щодо збирання доказів. Як зазначає С.М. Брайченко з огляду на специфіку та призначення адміністративного процесу, судовий розгляд справи ведеться не на засадах змагальності (як це відбувається в цивільному й господарському процесах), а з елементами судового слідства. Суд займає активну позицію, правомочний з власної ініціативи витребувати докази, визначати факти, що потребують доказової бази [1, с. 174].

3 цим можна погодитись, проте не відкидаючи взагалі принцип змагальності в адміністративному судочинстві. Можна казати лише про специфіку реалізації цього принципу. Як зазначається в літературі, класична модель змагального типу судочинства не передбачає наділення суду повноваженнями іншими, ніж відправлення правосуддя. Тобто суд не виконує функції, пов'язані зі збиранням доказів, які підтверджують/спростовують доводи однієї зі сторін, натомість активність суду спрямована на ведення процесу та вирішення справи по суті. Суд виступає арбітром у вирішенні спору й виконує лише одну, виключно йому властиву функцію - здійснення правосуддя. Втім у нашому випадку законодавець покладає на адміністративний суд повноваження щодо вжиття передбачених законом заходів для з'ясування обставин у справі з власної ініціативи [4, с. 182].

Відповідно до частини третьої статті 77 КАСУ, суд може збирати докази з власної ініціативи. Про витребування доказів з власної ініціативи суд постановляє ухвалу [3]. 
Оцінюючи зазначені положення КАСУ, вчені стверджують, що особливістю адміністративного судочинства вважається те, що в судовому процесі особі протистоїть потужний адміністративний апарат. У зв'язку із цим у сторін складаються істотно відмінні вихідні можливості. Для їх збалансування адміністративний суд повинен відіграти активну роль у судовому процесі 3 тим, щоб сприяти особі в захисті ії законних прав. Тому адміністративний суд має вжити всіх передбачених законом заходів, щоб порушені владою права були захищені. Така роль суду обумовлена тим, що переважно саме 3 ними в публічної адміністрації виникають конфлікти, або вона не вжила достатніх заходів, щоб цьому запобігти [6, с. 43].

Але тут виникає питання, чи повинен адміністративний суд відігравати згадану активну роль у справах за зверненнями суб'єктів владних повноважень, зокрема в справах про застосування санкцій за зверненнями суб' єктів владних повноважень?

Якщо виходити $з$ логіки класичного адміністративного судочинства, то в справах про застосування санкцій за зверненнями суб'єктів владних повноважень суд повинен за власною ініціативою збирати докази на користь фізичної чи юридичної особи, яка протистоїть суб'єкту владних повноважень, тим самим компенсуючи їх нерівність. Тобто суд має сприяти фізичній чи юридичній особі в доведенні відсутності фактів, на які спирається позивач - суб'єкт владних повноважень. Але така ситуація $є$ дещо неприродною.

На нашу думку, положення КАСУ стосовно того, що суд може збирати докази з власної ініціативи, не повинно поширюватись на справи про застосування санкцій за зверненнями суб'єктів владних повноважень. Суд в таких випадках має вирішувати справу виключно на підставі наданих сторонами доказів [3].

Виходячи з того, що в справах про застосування санкцій доказування має торкатись факту вчинення особою правопорушення, докази позивача - суб'єкта владних повноважень мають стосуватись виключно наявності відповідного факту, а докази відповідача - фізичної чи юридичної особи - відсутності відповідного факту. Так суд має оцінити, чиї докази є більш переконливими, й на підставі такої оцінки прийняти рішення про застосування чи незастосування санкцій.

Під час дослідження доказів суд здійснює оцінку доказів на належність, допустимість, достовірність і достатність. Саме за результатами дослідження доказів та їх відповідної оцінки суд робить висновок про наявність або відсутність обставин (фактів), що обгрунтовують вимоги й заперечення учасників справи.

Що ж торкається справ про застосування адміністративними судами санкцій за зверненнями суб'єктів владних повноважень, то доказування в цих справах у силу наявності особливостей, розглянутих вище, здійснюється простіше й приводиться до встановлення об'єктивної істини в питанні, чи існують у реальній дійсності підстави для застосування тих чи інших санкцій адміністративним судом. У свою чергу, тягар доказування наявності підстав для застосування санкцій покладається виключно на суб'єкта владних повноважень.

Висновки. Загалом можна зробити такі висновки: доказування в справах за зверненнями суб' єктів владних повноважень має такі особливості:

- по-перше, підстави звернення суб'єктів владних повноважень з адміністративними позовами абсолютно конкретно визначені в законах. Тобто тут головним завданням суду є перевірка того, наскільки вірно на підставі наявних доказів суб' єкт владних повноважень здійснив юридичну кваліфікацію діяння, яке стало підставою звернення до адміністративного суду. Якщо така кваліфікація здійснена вірно, то адміністративний суд може прийняти конкретно визначене рішення, яке також визначено законом, наприклад, накласти штраф, видворити за межі України, позбавити повноважень тощо;

- по-друге - документ, на підставі якого суб'єкт владних повноважень звертається з позовом до адміністративного суду, одночасно є доказом у цій справі. Особливість доказування в справах за зверненнями суб'єктів владних повноважень полягає в тому, що суб'єкт владних повноважень як позивач зобов'язаний доказувати наявність певних обставин, відповідно відповідач (фізична чи юридична особа) доводить відсутність цих обставин чи спростовує їх, тобто якщо відповідач не надав підтверджених доказів своїх заперечень, суд має задовольнити позов суб'єкта владних повноважень.

Особливості оцінки доказів у справах про застосування санкцій за зверненнями суб'єктів владних повноважень полягає в тому, що їі проведення виражає якісні характеристики доказів (належність, допустимість, достовірність і достатність), що є умовами процесу доказування та оцінюються за внутрішнім переконанням суду, яким він має керуватися під час прийняття рішення. 
Таким чином, можна стверджувати, що доктринальне розуміння процесу доказування досить суттєво відрізняється від фактичного стану правового регулювання. На нашу думку, якщо брати за основу положення сучасного КАСУ в частині доказування, то під доказуванням можна розуміти лише діяльність учасників справи щодо доведення обставин, на яких грунтуються вимоги та заперечення сторін. Якщо ж брати до уваги діяльність щодо збирання доказів, самого доказування, оцінки доказів тощо, то цю діяльність варто розглядати в рамках більш широкої категорії, а саме діяльності щодо реалізації принципу об’єктивної істини в адміністративному судочинстві.

\title{
Список використаних джерел:
}

1. Брайченко С. М. Особливості доказування в адміністративному судочинстві. Вісник Харківського начіонального університету внутрішніх справ. 2012. № 3. С. 174-178.

2. Кодекс адміністративного судочинства України : науково-практичні коментарі / за заг. ред. Р.О. Куйбіди. Київ : Юстиніан, 2009. 976 с.

3. Кодекс адміністративного судочинства України від 06 липня 2005 р. № 2747-IV / Верховна Рада України. Відомості Верховної Ради України. 2005. № 35-36, 37. Ст. 446.

4. Кононенко О.М. Принцип офіційного з'ясування всіх обставин справи в системі принципів адміністративного судочинства. Науковий вісник Дніпропетровського державного університету внутрішніх справ. 2015. № 2. С.179-185.

5. Король В.В. Зміст процесу доказування в адміністративному судочинстві України. Європейські перспективи. 2013. № 13. С. 79-84.

6. Основи адміністративного судочинства в Україні : навчальний посібник для юридичних факультетів та юридичних клінік / за заг. ред. Н.В. Александрової, Р.О. Куйбіди. 2-ге вид., доп. і перероб. Київ : КНТ, 2009. 248 с.

7. Цивільний процесуальний кодекс України. Відомості Верховної Ради України. 2004. № 40-41, 42. Ст. 492.

8. Цюпак О.П. Оцінка доказів в адміністративному судочинстві : правовий та логічний аспекти. Вісник Харківського національного університету внутрішніх справ. 2014. № 2. С. 179-186.

УДК 347.73

DOI https://doi.org/10.32844/2618-1258.2019.5-2.33

СОФ’ї̈ M.I.

\section{РОЛЬ І ЗНАЧЕННЯ ДІЯЛЬНОСТІ ГРОМАДСЬКИХ СУБ'ЄКТІВ У СФЕРІ РЕАЛІЗАЦІЇ ФІСКАЛЬНОЇ ПОЛІТИКИ В УКРАЇНІ}

\begin{abstract}
У статті визначено, що роль громадських суб'єктів у реалізації фіскальної політики не обмежується лише здійсненням заходів із громадського контролю. Діяльність таких суб'єктів спрямована також на налагодження взаємодії із представниками громадськості й органами державної влади 3 метою вироблення дієвих заходів із підвищення ефективності реалізації фіскальної політики, а також вирішення низки проблемних питань, які існують у цій сфері суспільних відносин; здійснення інформаційного забезпечення сфери реалізації фіскальної політики, зокрема підвищення обізнаності громадян у цій сфері та здійснення обміну інформацією з іншими суб'єктами таких правовідносин, у тому числі з міжнародними; представлення інтересів суб'єктів фіскальних правовідносин в органах державної влади та місцевого самоврядування; здійснення захисту прав, свобод та інтересів указаних суб'єктів із питань реалізації фіскальної політки. Зроблено висновок, що громадські суб'єкти у сфері реалізації фіскальної політики в Україні можуть бути
\end{abstract}

публічного права) 